\title{
METAPHORICAL THINKING OF STUDENTS WITH DIFFERENT SENSING PERSONALITY TYPES IN SOLVING ALGEBRA PROBLEMS
}

\author{
Dinda Wahyu Mei Relawati \\ Mathematics Education, Faculty of Mathematics and Natural Sciences, Universitas Negeri Surabaya \\ e-mail: dindarelawati16030174079@mhs.unesa.ac.id \\ Agung Lukito \\ Mathematics Education, Faculty of Mathematics and Natural Sciences, Universitas Negeri Surabaya \\ e-mail: agunglukito@unesa.ac.id
}

\begin{abstract}
This research aims at describing metaphorical thinking of students with varying personality types in solving algebra problems. The subjects of this study consist of two students of the same sex and equal mathematical abilities namely female students with guardian personality type and artisan personality type based on Keirsey personality type. Data collection methods used are problem solving task and task-based interview. The results show that metaphorical thinking of two subjects differ mainly in the component connect. In connect component, the guardian student is connects the problem given with the weekly savings process, while the artisan student connects with the farmer's hat and process of making a ladder. In relate component both students find common ideas between the problem given and the ideas they have. In explore component, the guardian student describes the similarity of ideas between the problem given with the weekly savings process and makes a model, while the artisan student describes the similarity of ideas with process of making a ladder using pictures and curves. In analyze component, the two students re-explain the previous steps that have been taken. Then in transform component, the two students change the model of their ideas. Whereas in experience component, both students do not apply the results obtained to solve the problems in new context.
\end{abstract}

Keywords: metaphorical thinking, algebra problem solving, sensing personality type.

\section{INTRODUCTION}

Algebra is one of the fields given to junior high school students. Based on Permendikbud Number 21 and 24 of 2016, algebra material began to be approved at the junior high school grade VII semester 1. Algebra is also a symbolic language used to express ideas in many branches of mathematics (Tabak, 2011: 68). This is in line with Watson (2007: 3) which states that algebra is an individual way to express generalizations about numbers, equations, relations, and functions by using symbols (usually consisting of letters or variables) as a simplification and help of problem aids.

However, Ramadhani (2016: 20) states that students do not understand the meaning of variables and make mistakes in solving equations in algebra material with one of the causes in the form of lack of mastery of algebra material that will have an impact on the problem-solving process. Novitasari (2018: 9) confirms with the results of his research that the average VIII grade junior high school students have not been able to reach the middle level on PISA content change and relationship questions with a percentage score for level 3 of $18.33 \%$ and level 4 of $11.67 \%$. Based on the description junior high school students in Indonesia are less able to solve mathematical problems, especially in the field of algebra. While Wilson et al (Bhat, 2014: 685) suggested that problem-solving has a special role in learning mathematics with the main goal of teaching mathematics and learning mathematics to develop the ability to solve various complex problems. This is also in line with NCTM (2000) which sets five standard processes in mathematics, namely problem solving, reasoning and proof, communication, connections, and representations. Based on these descriptions, make it clear that problem-solving is one of the important priorities in mathematics.

Salleh (Zakaria, 2009: 233) revealed that one of the abilities possessed in solving problems is by making analogies. Making analogies is a cognitive process of connecting information or meaning of a particular problem (source domain) to another (target domain) that corresponds to that process. For example, in solving problems related to algebraic equations can be analogous to the balance or can also be with the scales. By using this 
analogy students will more easily understand a mathematical concept because of the phenomenon that is per the mathematical concept and is often found in everyday life. Setiawan (2016: 210) explains that this analogy process is one of thinking that uses metaphors, which connects students' mathematical knowledge with real-world phenomena around, this is per the results of Arni's research (2019: 90) where students find metaphors from the problem of linear one-variable equations with scales and or seesaw. Thinking is called metaphorical thinking, Setiawan (2016: 210) defines that metaphorical thinking is a mental activity by using metaphors that are appropriate to the situation it faces to understand a concept.

Siler (1996: 7) revealed that metaphorming comes from meta (transcending) and phora (transference). Metaphorming is an activity that refers to the act of changing something (material) from one meaning to another. Bazzini (Lai, 2013: 32) views metaphors as a tool to explain or interpret mathematical ideas and processes in terms of real-world events, which involve everyday objects and processes.. Sterenberg (2008: 91) confirms that metaphors link abstract ideas to concrete images, thus evoking an experiential connection. Metaphors' thought supports embodied knowing and is not merely a communication or visualization device. Thus in metaphorical thinking, abstract concepts will be transformed into real objects in everyday life.

Carreira (2001: 267) explains that models and metaphors have a very close relationship. Each model formed has a metaphor in it. To make a mathematical model of a problem requires a relationship between two conceptual domains, but to develop such interconnections there must be a metaphor. Carreira's opinion is in line with the opinion of Mathieu (2009: 8) which revealed that a metaphor is the link we naturally make between two domains: one source domain, usually more concrete, and a target domain, usually more abstract. This allows us to better understand and think about the target domain. Thus in metaphorical thinking students are asked to connect real phenomena with the domain which will create a mathematical model and hopefully students can solve these problems. Siler (1996: 22-25) reveals the stage of metaphorical thinking, namely connection, discovery, invention, and application by involving the CREATE acronym which means "Connect, Relate, Explore, Analyze, Transform, Experience". The following is an explanation of CREATE based on the description of Siler (1996:26-31):

1. Connect two or more seemingly different things or ideas.

2. Relate linking a difference both objects and ideas to things that we already know or know, begins to observe their similarities..

3. Explore exploring similarities, drawing ideas, building models, playing roles, and describing those models.
4. Analyze things that have been thought of. Therefore, it is necessary to outline the ideas and models that already exist to find the relationship between these ideas and models.

5. Transform discover or invent something new based on your connections, explorations, and analysis.

6. Experience apply your drawing, model, or invention in as many new contexts as possible.

Each student has a different way of thinking as in determining a choice or decision making due to differences in the personality of each individual. The results of Barhaghtalab's research (2016: 790) show that thinking has a significant correlation with personality type, so there is a possibility that personality is one of the factors in the thought process. One personality classification is done by David Keirsey. Keirsey (1998) describes briefly the classification of personality types based on the way a person behaves towards an event. He distinguishes it into two, which is to observe as a type of sensing and introspective as an intuitive type. We only focus on the type of sensing, because this type requires more information and real memory to behave towards an event. With this real information, it is possible to have a connection with metaphorical thinking.

There are two types of sensing, guardian, and artisan. Broadly speaking, guardian personality types have intelligence in logistics where this intelligence is used in organizing a problem correctly before carrying out a process, so everything must be confirmed first (Advisor, 2017). Artisan-type people have intelligence in tactics where this ability is used in seeing situations quickly, evaluating various choices, and taking actions to obtain the desired results (Advisor, 2017). Because it is possible the influence of personality types in decision making which later will have an impact on problem-solving.

Based on some of the descriptions above, the purpose of this study is to describe the metaphorical thinking of students with different sensing personality types in solving algebra problems.

\section{METHODS}

This research is a qualitative descriptive study. Based on the type, this research aims to describe the metaphorical thinking of students with different sensing personality types in solving algebraic problems related to material number patterns. This research data was obtained from the results of students' problem-solving assignments and taskbased semi-structured interviews to clarify written data and explore information that might not be present in written data about students' metaphorical thinking in solving algebraic problems. The subjects in this study consisted of two eighth grade students of junior high school.

Subject selection was done by giving Keirsey personality type tests so that the chosen subjects were one 
student with guardian personality and one student with artisan personality with both students being female and having equivalent mathematical abilities based on the results of daily tests on material number patterns in the range of scores 86-100. Researchers control the sex of research subjects to avoid differences in data influenced by sex, this is confirmed by the results of Mubarok's research (2019) which shows there are differences in the thought processes between male and female students. Researchers assume that material number patterns have analogous processes that are per metaphorical thinking, this is in line with the results of the research of Kadir and Ulfah (2013) that solving the problem look for a pattern, students can connect the relationship between one pattern with another pattern. Researchers also assume that with high daily test scores mastering material number patterns.

Students' metaphorical thinking data come from problem-solving tasks and task-based semi-structured interviews. The problem-solving task given to the subject is a non-routine math problem related to material number patterns. Interviews are used to clarify written data and explore information that might not be obtained from written data about students' metaphorical thinking in solving algebraic problems. The data that has been obtained will be analyzed using three stages, namely data condensation, data display and drawing conclusions (Miles \& Huberman, 2014: 12), based on metaphorical thinking indicators adapted from Siler (1996), Setiawan (2016) and Arni (2019) presented in Table 1.

Table 1. Indicators of Metaphorical Thinking

\begin{tabular}{|c|c|c|}
\hline $\begin{array}{l}\text { Metaphorical } \\
\text { Thinking } \\
\text { Stages }\end{array}$ & $\begin{array}{c}\text { Components } \\
\text { of } \\
\text { Metaphorical } \\
\text { Thinking } \\
\end{array}$ & Indicators \\
\hline \multirow{3}{*}{ Connection } & Connect & $\begin{array}{l}\text { Linking two or more } \\
\text { different ideas (situations) }\end{array}$ \\
\hline & \multirow[t]{2}{*}{ Relate } & $\begin{array}{l}\text { Linking ideas (situations) } \\
\text { that appear to be different } \\
\text { from known ideas } \\
\text { (situations) }\end{array}$ \\
\hline & & $\begin{array}{l}\text { Find common ideas } \\
\text { (situations) }\end{array}$ \\
\hline \multirow{3}{*}{ Discovery } & \multirow[b]{2}{*}{ Explore } & $\begin{array}{l}\text { Describe the similarity of } \\
\text { ideas (situations) }\end{array}$ \\
\hline & & $\begin{array}{l}\text { Make a draw/model of } \\
\text { ideas (situations) that have } \\
\text { been obtained }\end{array}$ \\
\hline & Analyze & $\begin{array}{l}\text { Analyze the results that } \\
\text { have been obtained from } \\
\text { the previous stage } \\
\text { (connect, relate, and } \\
\text { explore) }\end{array}$ \\
\hline Invention & Transform & $\begin{array}{l}\text { Change the form of draws, } \\
\text { models, or ideas that have } \\
\text { been made to find } \\
\text { something new }\end{array}$ \\
\hline Application & Experience & $\begin{array}{l}\text { Apply draws, models, or } \\
\text { ideas in various new } \\
\text { contexts }\end{array}$ \\
\hline
\end{tabular}

The algebra problem used in this study includes the following 2 questions.

1. Pay attention to the picture of the following square shape.
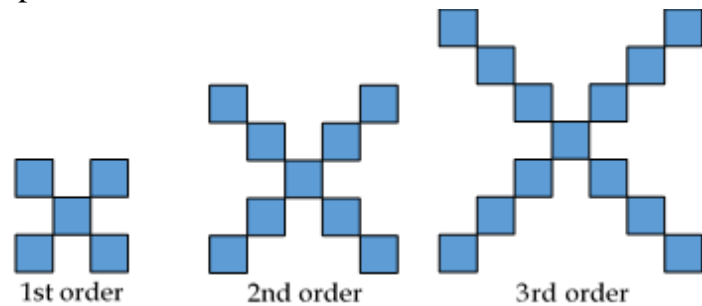

The relationship between the two sequential arrangements above is the same.

a. Determine the number of square shapes in each arrangement from the 1 st order to the 10th arrangement.

b. Determine the number of square shapes in the $n$th arrangement.

2. Pay attention to the picture of the following cubeshaped arrangement.

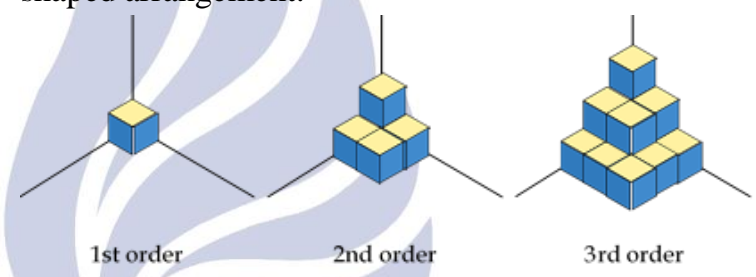

The relationship between the two sequential arrangements above is the same.

a. Determine the number of cuboid shapes in each arrangement from the 1 st order to the 8th arrangement.

b. Determine the number of cuboid shapes in the $n$th arrangement.

\section{RESULTS AND DISCUSSIONS}

Based on data analysis of problem-solving tasks results and interviews of Guardian subject (SG) and Artisan subject (SA), a description of metaphorical thinking of students with different sensing personality types in solving algebra problems.

\section{Guardian Students' Metaphorical Thinking in Solving Algebra Problems}

Based on the results of the analysis conducted on SG in solving algebra problems with CREATE criteria can be revealed as follows.

The following excerpts of SG interviews relating to the connect component.

PG01: Where did you get the idea to solve the problem that I gave?

SG01: From my daily life, I save money, miss.

PG02: How did you get that idea?

SG02: I got the idea from my routine. The thing is, I save money every week. Initially saving 50.000 IDR then every week the 
next plus 5.000 IDR, well from there, miss.

PG03: Why use the idea?

SG03: Because I think my saving system, which is the same as this number pattern every week, has the same addition, miss. For example in the first week I saved 50.000 IDR, then the second week I would save the same as the first week but I added 5.000 IDR so the second week I saved 55.000 IDR, while the third week 60.000 IDR, until the following week with the same pattern. So, if I save the system the previous savings plus 5.000 IDR if this pattern was originally 5 continues to be 9 means plus 4 , then 9 is finished 13 is also added 4 . Well from there it's already seen that the previous pattern is always added 4. Viewed from here the addition is always still, miss.

PG04: Do you have any other ideas? Besides the saving process.

SG04: Nothing, miss, I think that's all, miss.

In the connect component, SG connects the given problem by saving it weekly. SG only found one idea, but SG explained in detail the relationship of the pattern of how she saved the same as the problem given, both of which had a fixed difference. SG explained that the relationship did not use writing but verbally, in this case in accordance with Dewiyani's statement (2017: 307) that the guardian type did not express ideas and information obtained in written form.

The following excerpt from the SG interview relates to the relate component.

PG07: Explain, how are these ideas related to the problem given?

SG07: The link is like this, miss. I saved it also patterned, then the system is also the same as this pattern (a given problem) where the enhancers are always fixed, so the connection equally has a permanent enhancer.

PG08: What links saving ideas with this problem?

SG08: Addition system earlier, miss. If saving the previous week was added by 5.000 IDR while this pattern (the problem is given), the previous pattern was added by 4 , miss.

PG09: How did you find that relationship?

SG09: Because I had already found a pattern in the problem, suddenly I remembered how I saved every week. So, I found that my savings system was like this in this pattern.

Furthermore, in the relate component, SG finds similarities between the problems given and the way she saves each week. SG explained the similarities between ideas found in a fixed difference. In the explore component, SG describes verbally the similarities between the ideas she gets. Where she saves every week has a difference of 5.000 IDR for two consecutive weeks, while the problem is given, has a difference of 4 for two sequential arrangements, so SG explains that the similarity between ideas lies in a fixed difference (different) and has the same pattern. Then SG makes the idea in the form of a mathematical model like in Figure 1 which aims to facilitate it in solving problem number $1 \mathrm{a}$, where $m_{n}$ SG is defined as the $n$th week.

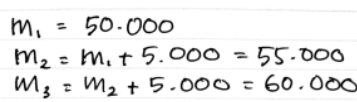

Figure 1. Model made by SG

In the analyze component, SG explains the steps previously taken verbally, starting from how SG connects and finds similarities between ideas and problems, then redefines the similarities and makes a model. The following excerpt from the SG interview is related to the analyze component.

PG19: Explain how you found the relationship between saving and this pattern?

SG19: Because there was a constant addition to the next pattern using the previous pattern added to the difference in the pattern, so I suddenly remembered the same way I saved it, the addition was fixed, miss.

PG20: Explain the relationship between ideas?

SG20: The relationship in the form of saving my second week is the same as the first week plus 5,000 IDR, while the second pattern is 9 equal to 5 plus 4 . So, the next pattern is the same as the previous pattern plus the permanent addition, miss.

PG21: Okay, then explain how to make this model (Figure 1) and what this model means (Figure 1)?

SG21: So let's say the variable $m \_1$ for the first week, $m \_2$ for the second week, and $m \_n$ for the nth week, for example, $m_{-} 1$ is 50,000 IDR, while $\mathrm{m} \_2$ is 55,000 IDR, meaning $\mathrm{m} \_2$ is the same as $\mathrm{m} \_1$ plus 5,000 IDR so it is made like this (pointing the model in Figure 1). From here, I mean to make such a model be more easily understood and concise, miss.

In the transform component, SG converts the model that has been made into the next pattern similar to the previous number pattern plus a fixed difference to solve problem number 1a. From changing the model SG concluded that she got the arithmetic sequence has a difference of 4 , so she solved problem number 1 a by adding the previous number 4 and registering it as in Figure 2. While solving problem number $1 \mathrm{~b}, \mathrm{SG}$ did not use the model but SG used $n$th term formula for arithmetic sequences.

The following excerpt from the SG interview is related to the experience component. 
PG25: Yes, alright. Next, can you use the idea of solving problem number 1 in number 2 ?

SG25: The concept is similar to number 1, miss. But the enhancers in number 2 are not fixed. Number 2 has the addition of $n^{2}$, different from number 1 which is 4 .

PG26: Well, about the idea that you use to answer number 2 is the same as number 1 ?

SG26: It's almost the same as the sum with the previous number, but the addition is not fixed for number 2 , miss.

PG27: So, did you use the previous idea or not?

SG27: No, miss. But the addition was changed with $n^{2}$.

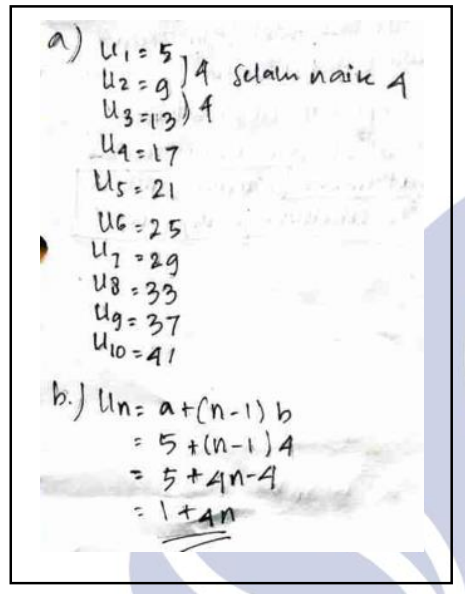

Figure 3. Results of SG Problem Solving Task Problem Number 1

In the experience component, SG explains that the model she got from problem number 1 can't be used in problem number 2. SG explains that the arithmetic sequence in number 2 does not have a fixed difference, but each subsequent term is obtained from the previous term plus $n^{2}$, as can see in Figure 3. Then, SG records each tribe to find a fixed difference and knows that problem number 2 is a three-tiered arithmetic sequence. Therefore, SG uses a multilevel arithmetic sequence formula to solve problem number $2 b$ presented in Figure 4. Thus in the experience component, SG does not apply the previous idea but rather it applies a new idea.

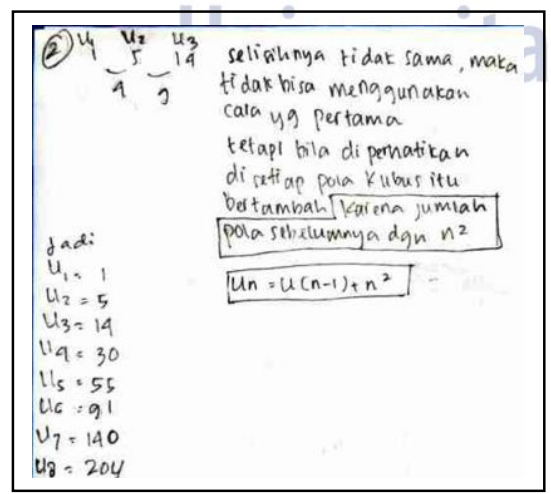

Figure 4. The Results of SG Problem Solving Task Problem Number 2 in the First Way

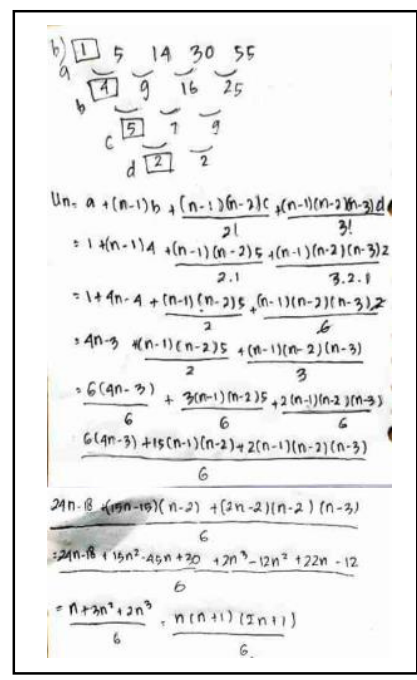

Figure 2. The Results of SG Problem Solving Task Problem Number 2 in the Second Way

\section{Artisan Students' Metaphorical Thinking in Solving Algebra Problems}

Based on the results of the analysis conducted on SA in solving algebra problems with CREATE criteria can be revealed as follows.

In the connect component, the SA connects the problem given by making a ladder and the diameter of the farmer's hat (caping). SA explains the relationship between how stairs are made and the problem given using pictures and mentions if both have fixed patterns and differences as shown in Figure 5.

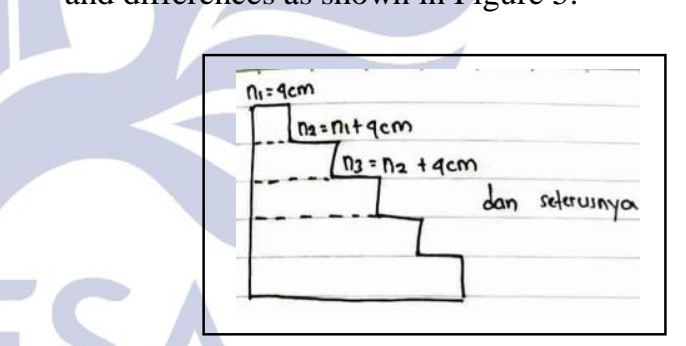

Figure 5. Illustration of SA Idea in the Connect Components

However, for caping diameter, SA can only assume if caping has a fixed and patterned difference. The following excerpts from an SA interview in explaining the relationship between making stairs and caping with the given problem.

PA03: Why use the idea?

SA03: Because if the first rung is $1 / 2$ meter long, then the second rung is 1 meter long, the third rung is $11 / 2$ meter long, I can conclude that each ladder goes down to form a pattern with a fixed difference of $1 / 2$ meter and length the steps are the same as the previous steps plus the difference, and it turns out the same as this problem, miss . If this problem starts from 5 to 9 to 13 , you can conclude, if the difference is 4 and the pattern in the form of the previous pattern is always added to 4 . 
PA04: Do you have any other ideas? Besides the process of making stairs.

SA04: Farmer pack hat, the diameter is getting down the bigger, forming a fixed pattern and the difference is fixed, miss. But this is just my hypothesis, miss. Because it looks like that, but don't know more, miss.

Then, in the relate component, SA is more familiar with making stairs than caping because it is more often encountered and used by SA. SA explained that the making of stairs and the problems given have in common that lies in a fixed difference and the next pattern is obtained from the previous pattern plus a fixed difference. The following excerpt from the SA interview relates to the relate component as follows.

PA10: Then, what connects the idea of making stairs with this problem?

SA10: Yes, that was earlier, miss. Because the difference is fixed and the pattern is fixed. If the stairs that were the difference were $1 / 2$ meter while the problem was the difference 4 . Then the pattern was the same, namely the previous pattern plus the difference, miss.

In the explore component, the SA describes the similarities between the ideas of understanding the problem and is related to the curve depicted as shown in Figure 6. For SA, the curves formed are more like stairs, so the SA looks for the relationship between the problem given and the ladder. The following is an interview excerpt from the SA.

PA11: Oh well, then how did you find that relationship?

SA11: Because if I think of a pattern like question number 1 , if the curve is drawn it will be like this, miss (Figure 6), and it looks like a ladder, not suddenly thinking of going to the stairs.

PA12: Explain, how is the relationship between ideas?

SA12: Yes, it was sis, the pattern of stairs, and the problem was fixed and the difference was also fixed. From the difference, if you draw a curve, it will form a straight line. So, the relationship is from the fixed difference, miss. So, I made this curve model with the stairs earlier.

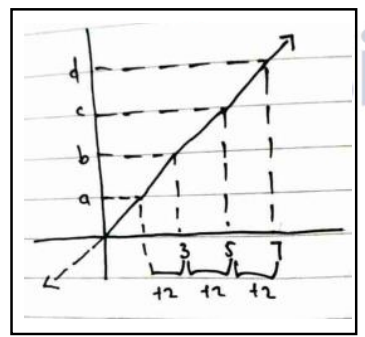

Figure 6. Illustration of SA in Describing the Relationship of Curves and Stairs

Thus, SA thinking starts from the given problem which is modeled in the form of a curve then connected to the stairs. SA draws curves and stairs to make it easier to apply the given problem. SA more often poured his ideas in the form of pictures and writings such as the connect and explore components. SA shows its artistic nature by pouring out his ideas using drawings by the statement of Keirsey (1998), and Dewiyani (2017: 307) also states that the type of artisan gives more scribbles, and makes writing and drawing in understanding problems and planning problem-solving.

In the analyze component, the SA explains the steps that have been taken previously, starting from how the SA connects and finds similarities between ideas and problems, then redefines the similarities and makes a picture. SA also explains if the ladder and the problem are given have differences where the first ladder has a length according to a fixed difference value. While the first pattern on a given problem does not begin with a fixed difference value. However, both have the same pattern with a fixed difference.

In the transform component, SA changes the model that has been made into the next pattern similar to the previous number pattern plus a fixed difference. From changing the model in Figure 6, the SA concludes that if the pattern is straight, it is most likely that the difference is fixed and only needs to calculate the difference which is then applied according to the model she made. For SA the results of changing the model are used to solve problem number 1a, while in solving problem number $1 \mathrm{~b}$, the SA does not use the model but uses the $n$th term formula for arithmetic sequences presented in Figure 7.

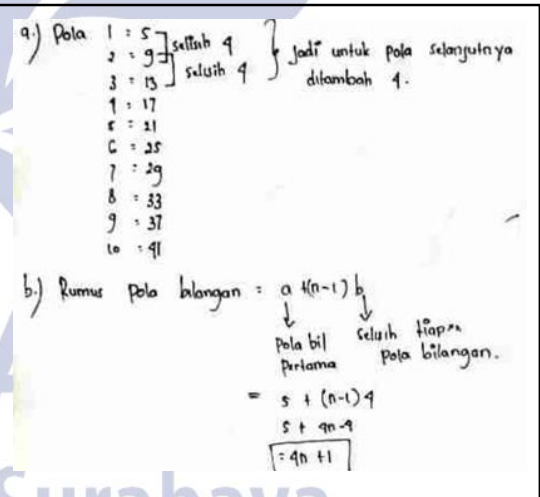

Figure 7. Results of SA Problem Solving Task Problem Number 1

In the experience component, SA explains that the model she got from problem number 1 can't be used in problem number 2. SA explains the arithmetic sequence in number 2 does not have a fixed difference, but each subsequent term is obtained from the previous term plus $n^{2}$. The following is an excerpt from the interview explanation of the $\mathrm{SA}$ in the experience component.

PA25: Yes, already. Next, can you use the idea of solving problem number 1 in number 2 ?

SA25: You can't, miss, because the difference isn't fixed, miss.

PA26: Then what ideas do you use? 
SA26: I looked at the difference, then looked for a relationship with $\mathrm{n}$ what it was, and it turned out that the selection was $n^{\wedge} 2$.

PA27: Do you think there is something in common with the making of the stairs?

SA27: not the same, miss. Because the difference is different so the pattern is not as regular as the stairs and question number 1 .

PA28: Alright. Then how do you use the difference idea $\mathrm{n}^{\wedge} 2$ in solving problems at number 2 ?

SA28: Yes, I list as I answer it, miss (Figure 8). Then problem $2 \mathrm{~b}$ uses the same method as problem $1 \mathrm{~b}$.

SA is not careful when calculating problem number 2, she applies the arithmetic formula but does not reexamine the results, it can be seen in Figure 8. In this case, by the statement of Keirsey (1998) that the artisan personality type has the nature to dare to look for other ways that can be applied but often careless and in a hurry so that causes inaccurate answers. Thus the experience component, SA does not apply the previous idea.

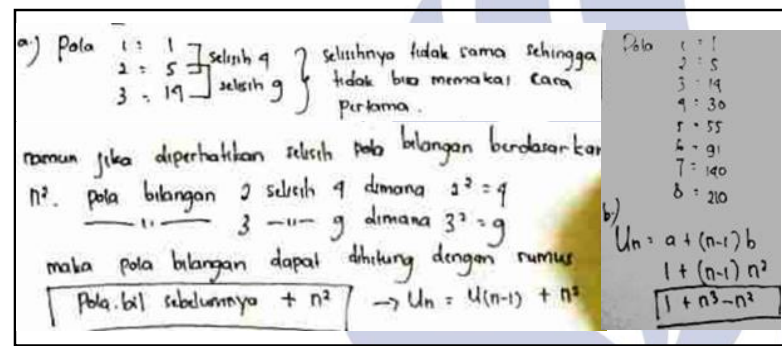

Figure 8. Results of SA Problem Solving Task Problem Number 2

\section{Comparison of Guardian and Artisan} Metaphorical Thinking in Solving Algebra Problems.

Based on the results and discussion each subject has similarities and differences in thinking on the CREATE component in solving algebra problems presented in Table 2.

Table 2. Comparison of the Metaphorical Thinking of Guardian and Artisan subjects in Solving Algebra Problems

\begin{tabular}{|c|l|l|}
\hline $\begin{array}{c}\text { Components } \\
\text { of } \\
\text { Metaphorical } \\
\text { Thinking }\end{array}$ & \multicolumn{1}{c|}{$\begin{array}{c}\text { Guardian } \\
\text { Subject }\end{array}$} & Artisan Subject \\
\hline Connect & $\begin{array}{l}\text { Connect the } \\
\text { problem given by } \\
\text { saving. }\end{array}$ & $\begin{array}{l}\text { Connect the } \\
\text { problem given by } \\
\text { making a ladder } \\
\text { and hat for } \\
\text { farmers. }\end{array}$ \\
\hline Relate & $\begin{array}{l}\text { Find common } \\
\text { ideas between } \\
\text { problems given } \\
\text { by saving each } \\
\text { week. }\end{array}$ & $\begin{array}{l}\text { Find the } \\
\text { similarity of ideas } \\
\text { between the } \\
\text { problems given } \\
\text { and the making of } \\
\text { stairs. }\end{array}$ \\
\hline
\end{tabular}

\begin{tabular}{|c|c|c|}
\hline $\begin{array}{l}\text { Components } \\
\text { of } \\
\text { Metaphorical }\end{array}$ & $\begin{array}{c}\text { Guardian } \\
\text { Subject }\end{array}$ & Artisan Subject \\
\hline Explore & $\begin{array}{l}\text { Describe the } \\
\text { similarity of ideas } \\
\text { between the } \\
\text { problems given } \\
\text { by oral savings } \\
\text { and mathematical } \\
\text { models. }\end{array}$ & $\begin{array}{l}\text { Describe the } \\
\text { similarity of ideas } \\
\text { between problems } \\
\text { given by making } \\
\text { stairs through } \\
\text { drawings and } \\
\text { curves. }\end{array}$ \\
\hline Analyze & $\begin{array}{l}\text { Re-explain the } \\
\text { previous steps } \\
\text { that have been } \\
\text { taken. }\end{array}$ & $\begin{array}{l}\text { Re-explain the } \\
\text { previous steps } \\
\text { that have been } \\
\text { taken and find the } \\
\text { differences } \\
\text { between ideas. }\end{array}$ \\
\hline Transform & $\begin{array}{l}\text { Changing the } \\
\text { model made into } \\
\text { the next pattern is } \\
\text { the same as the } \\
\text { previous pattern } \\
\text { plus a fixed } \\
\text { difference. }\end{array}$ & $\begin{array}{l}\text { Changing the } \\
\text { model made into } \\
\text { the next pattern is } \\
\text { the same as the } \\
\text { previous pattern } \\
\text { plus a fixed } \\
\text { difference. }\end{array}$ \\
\hline Experier & $\begin{array}{l}\text { Not applying the } \\
\text { previous idea, but } \\
\text { applying a } \\
\text { formula of } \\
\text { multilevel } \\
\text { arithmetic. }\end{array}$ & $\begin{array}{l}\text { Not applying the } \\
\text { previous idea, but } \\
\text { applying the } \\
\text { arithmetic } \\
\text { sequence } \\
\text { formula. }\end{array}$ \\
\hline
\end{tabular}

Based on Table 2, in the connect component, SG connects the given problem with the weekly saving process, while the SA connects the problem given with making ladder and farmer's hat. In this case, it appears that SA is bolder and more confident in using varied ideas and conveying their ideas verbally and visually compared to SG that only uses one idea and delivered verbally, this is in line with the statement of Keirsey (1998). In the relate component, SG finds the similarity of ideas between the problems given and the saving process every week, while the SA finds the similarity of ideas with the making of a ladder. Both subjects find the similarity of ideas in the form of a fixed difference.

In the explore component, SG describes the similarity of ideas between problems given by the process of saving verbally and makes a mathematical model, while the SA describes the similarity of these ideas by making stairs through pictures and curves. In this case, it shows that SG is more often conveying the idea verbally, compared to the SA which prefers to draw pictures/illustrations. It shows that SA with an artistic spirit more often gives scribbles and makes pictures in understanding or planning problem solving, this is in line with Dewiyani's (2017) opinion.

In the analyze component, both subjects reiterate the results obtained from the previous steps, but the SA also explains the difference between the ideas he found and the problems faced. This shows that SA is open-minded 
so that it discovers differences between ideas, compared to SG who acts carefully and does not find differences between ideas.

In the transform component, the two subjects conclude by changing the model that has been made into the next pattern the same as the previous pattern added with different from each pattern. Then in the experience component, the two subjects do not apply the results obtained previously to solve the problem in a new context. However, SG uses a multilevel arithmetic sequence formula, while the SA uses an arithmetic sequence formula. In this case, the SA acts hastily and courageously so that it is careless in applying other ways that are less precise, in contrast to SG which acts cautiously and methodically in applying other ways.

\section{CLOSURE}

\section{Conclusion}

Based on the results of the analysis and discussion above, it can be concluded that students' metaphorical thinking with sensing personality types has differences, especially in the connect component. In connect component, the guardian student is connecting the problem given with the weekly savings process, while the artisan student connects with the farmer's hat and process of making a ladder. In relate component both students find common ideas between the problem given and the ideas they have. In explore component, the guardian student describes the similarity of ideas between the problem given with the weekly savings process and makes a model, while the artisan student describes the similarity of ideas with the process of making a ladder using pictures and curves. In analyze component, the two students re-explain the previous steps that have been taken. Then in transform component, the two students change the model of their ideas. Whereas in experience component, both students do not apply the results obtained to solve the problems in new context.

\section{Suggestions}

Based on research that has been done, the advice given by researchers is as follows..

1. The results of this study indicate that there are differences in the metaphorical thinking of guardians and artisan students in solving algebra problems. Therefore, for teachers, the results of this study can be considered in providing opportunities for students to solve problems using the methods they have.

2. The results of this study are limited to the subjects of sensing personality types namely guardians and artisan. We assume in metaphorical thinking other factors can influence besides sensing personality types. If you want to do similar research, it can be viewed from other aspects, for example, gender, MBTI personality type, learning style, or mathematical ability.

\section{REFERENCES}

Advisor, K. C. 2019. Keirsey.com. Retrieved Mei 25, 2019, from http://www.keirsey.com/personalityzone/cz34.asp

Arni, N. C. 2019. Profil Berpikir Metaforis Siswa SMP Dalam Memecahkan Masalah Matematika Ditinjau Dari Gaya Kognitif. Jurnal Ilmiah Edukasi Matematika. Doi:

http://dx.doi.org/10.25139/smj.v7i2.1520

Barhaghtalab, E. Y., \& Sharafi, M. 2016. The relationship between personality traits and critical thinking among female administrative officers in four districts and department of education in shiraz. Research Journal of Pharmaceutical, Biological and Chemical Sciences, 7(1), 790-795.

Bhat, A. M. 2014. Effect of Problem Solving Ability on the Achievement in Mathematics of High School Students. India: Aligarh Muslim University, Department of Education. pp. 685-688.

Carreira, S. 2001. Where There's a Model, There's a Metaphor: Metaphorical Thinking in Students' Understanding of a Mathematical Model. 3:4, 261287, DOI: 10.1207/S15327833MTL0304_02

Dewiyani, M. J., Budayasa, I. K., \& Juniati, D. 2017. Profil Proses Berpikir Mahasiswa Tipe Kepribadian Sensing dalam Pemecahan Masalah Logika Matematika. Cakrawala Pendidikan. Doi: https://doi.org/10.21831/cp.v36i2.13119

Kadir, \& Ulfah, S. M. J. 2013. Pengaruh Penerapan Strategi Pemecahan Masalah "Look For A Pattern" Terhadap Kemampuan Penalaran Analogi Matematik Siswa SMP. Prosiding Konferensi Nasional Pendidikan Matematika V. Fakultas MIPA, Universitas Negeri Malang.

Keirsey, D. 1998. Please Understand Me II: Temperament, Character, Intellegence. California: Nemesis Book Company.

Kemendikbud. 2016. Permendikbud Nomor 21 Tahun 2016 Tentang Standar Kompetensi Lulusan Untuk Pendidikan Dasar dan Menengah. Jakarta: Kemendikbud.

Kemendikbud. 2016. Permendikbud Nomor 24 Tahun 2016 tentang Kompetensi Inti dan Kompetensi Dasar pada Kurikulum 2013 pada Pendidikan Dasar dan Pendidikan Menengah. Jakarta: Kemendikbud.

Lai, M. Y. 2013. Constructing Meanings of Mathematical Registers Using Metaphorical Reasoning and Models. 
Mathematics Teacher Education and Development. Flinder University. Vol. 15 No. 1.

Mathieu, A. 2009. Metaphors in Mathematics. Retrieved from http://ssrn.com/abstract=1478871. pp. 8 .

Miles, M. B., Huberman, A. M., \& Saldana, J. 2014. Qualitative Data Analysis: A Method Sourcebook: Third Edition. USA: SAGE Publications.

Mubarok, M. A., \& Kurniasari, I. 2019. Berpikir Kreatif Siswa dalam Pemecahan Masalah Matematika Ditinjau dari Gaya Kognitif Field Independent dan Jenis Kelamin. Jurnal Ilmiah Pendidikan Matematika, Vol. 8, No. 2, ISSN :2301-9085. Universitas Negeri Surabaya.

National Council of Teachers of Mathematics (NCTM). 2000. Principles and Standards for School Matheatics. Reston, Virginia.

Novitasari, E. D., Murtiyasa, B., Kom, M., Setyaningsih, N., \& Sutama, M. P. 2018. Analisis Kemampuan Siswa dalam Menyelesaikan Soal-soal PISA Konten Change and Relationships pada Siswa Kelas VIII SMP Negeri 1 Puhpelem (Doctoral dissertation, Universitas Muhammadiyah Surakarta).

OECD. 2015. PISA 2015 Results in Focus, (Online), (https://www.oecd.org/pisa/pisa-2015-results-infocus.pdf, diakses 25 Mei 2019).

Ramadhani, A. N., Yuwono, I., \& Muksar, M. 2016. Analisis Kesalahan Siswa Kelas VIII SMP Pada
Materi Aljabar serta Proses Scaffolding-nya. Jurnal Silogisme: Kajian Ilmu Matematika dan Pembelajarannya, Vol. 1, No.1, Oktober 2016. ISSN: 2527-6182.

Setiawan, W. 2016. Profil Berpikir Metaforis (Metaphorical Thinking) Siswa SMP dalam Memecahkan Masalah Pengukuran Ditinjau dari Gaya Kognitif. Jurnal Matematika Kreatif-Inovatif, Vol. 7, No. 2, Desember 2016. Universitas Negeri Surabaya.

Siler, T. 1996. Think Like a Genius. New York: Bantam Book.

Sterenberg, G. 2008. Investigating Teachers' Images of Mathematics. Journal of Mathematics Teacher Education, 11 (2), 89-105, DOI: 10.1007/s10857-0079062-8.

Tabak, J. 2011. Algebra: Sets, Symbols, and the Language of Thought (Revised Edition). New York: Fact On File.

Watson, A. 2007. Paper 6: Algebraic Reasoning. Dalam Key Understanding in Mathematics Learning. Nuffield Foundation. University of Oxford.

Zakaria, E. \& Yusoff, N. 2009. Attitudes and ProblemSolving Skills in Algebra Among Malaysian Matriculation College Students. European Journal of Social Sciences. Volume 8, Number 2, p. 233.

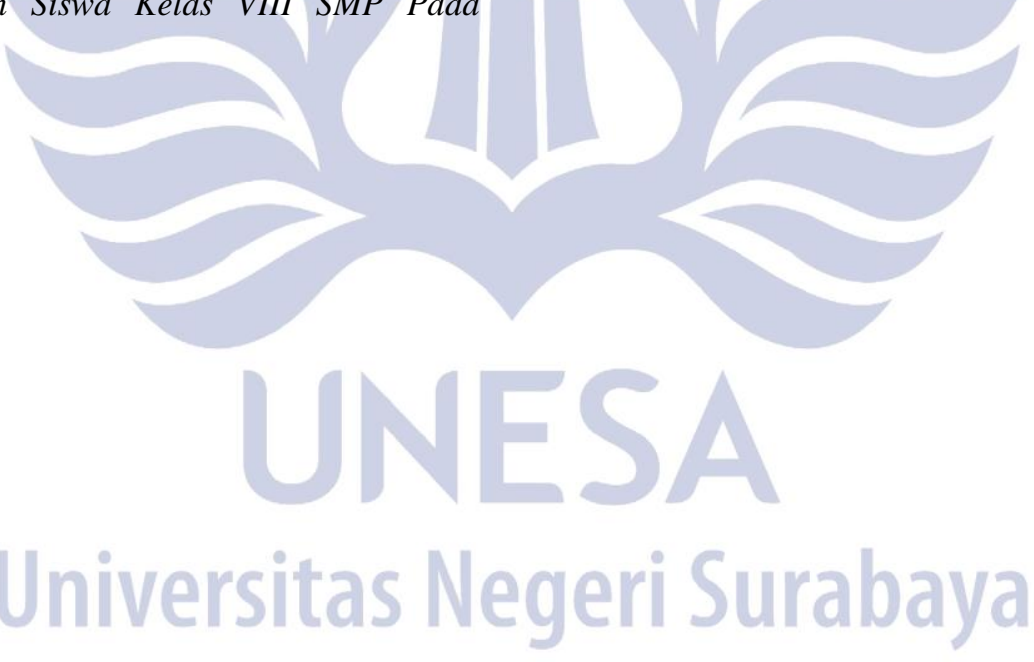

